\title{
More data on the Ross procedure
}

\author{
Tirone E. David, MD
}

\author{
From the Division of Cardiovascular Surgery, Peter Munk Cardiac Centre, Toronto General Hospital and Univer- \\ sity of Toronto, Toronto, Ontario, Canada. \\ Disclosures: Author has nothing to disclose with regard to commercial support. \\ Received for publication June 17, 2018; revisions received June 17, 2018; accepted for publication June 18, 2018; \\ available ahead of print Aug 9, 2018. \\ Address for reprints: Tirone E. David, MD, 200 Elizabeth St, 4N453, Toronto, Ontario M5G 2C4, Canada (E-mail: \\ tirone.david@uhn.ca). \\ J Thorac Cardiovasc Surg 2019;157:142-3 \\ $0022-5223 / \$ 36.00$ \\ Copyright $(\underset{2018}{ } 20 \mathrm{by}$ The American Association for Thoracic Surgery \\ https://doi.org/10.1016/j.jtcvs.2018.06.051
}

In this issue of the Journal, Sharifulin and colleagues ${ }^{1}$ from Novosibirsk, Russian Federation, describe their experience with the Ross procedure in 792 consecutive patients operated on during a 17-year period. This is certainly the largest series ever published from a single institution. The patients' mean age was $46.5 \pm 12.4$ years (range, 18-67 years), and the technique of aortic root replacement with the pulmonary root was performed in all patients (in 20 patients, the autograft was sutured into a Dacron polyester fabric graft with sinuses before implantation in the aortic position). Unique in this experience is the fact that the right side of the heart was reconstructed with a xenograft valve in 588 cases $(74.1 \%)$ and with a polytetrafluoroethylene conduit in 20 $(2.5 \%)$; unfortunately, however, the mean follow-up was too short to determine the effect of this approach on the durability of the right-sided valve. There were 23 operative deaths $(2.9 \%)$ and 22 late deaths during a mean follow-up of $6.5 \pm 3.2$ years, with 38 patients unavailable for follow-up. Twenty-four patients developed infective endocarditis of the pulmonary autograft. Of these, 11 required surgery. This incidence of endocarditis, particularly endocarditis of the pulmonary autograft, appears to be a bit higher than in series from Europe and North America. ${ }^{2-4}$ In my institution's experience with a much smaller series of 212 patients undergoing the Ross procedure but with a median follow-up of 18 years, only 7 patients developed endocarditis of the failing pulmonary homograft, for an incidence of $3.4 \%$ at 20 years, and not a single patient developed endocarditis of the pulmonary autograft. ${ }^{2}$ In the study of Sharifulin and colleagues, ${ }^{1} 25$ patients developed moderate aortic insufficiency (AI), and 37 developed severe AI. This is also a higher incidence of pulmonary autograft dysfunction than in 3 recently published series of the Ross procedure. ${ }^{2-4}$ There is an encouraging finding in Figure 2 of the article, however, in which the graphic shows nonprogressive rates of moderate and severe AI during the first decade of follow-up, suggesting a technical problem during transference of the pulmonary root from the right to the left side of the heart. What this study establishes

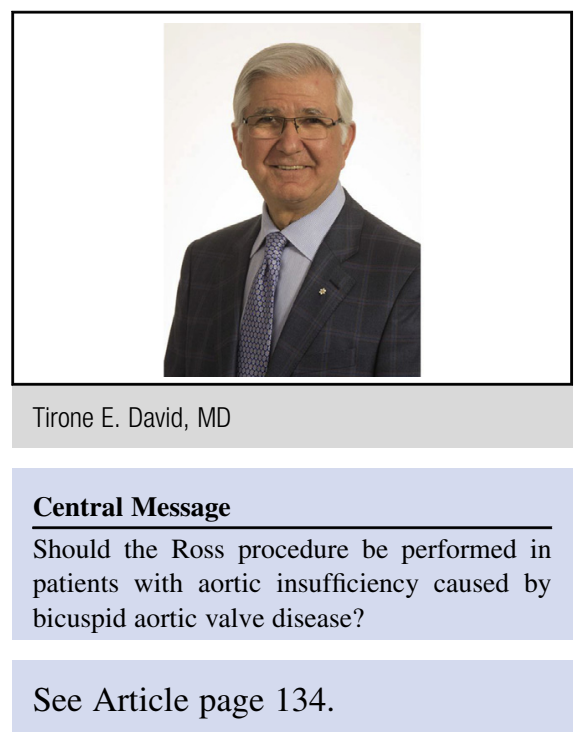

is that the preoperative AI caused by bicuspid aortic valve (BAV) disease is associated with high rates of postoperative $\mathrm{AI}$ and reoperation on the pulmonary autograft. This phenotype of BAV was also found to be associated with dilatation of the aortic annulus, aortic root, and ascending aorta with time. Other investigators have also described this problem. $^{2-4}$

Should the Ross procedure be offered to patients with AI caused by BAV? I have been reluctant to do this type of aortic valve replacement in these patients, particularly if the aortic annulus is larger than $27 \mathrm{~mm}$, for more than a decade. Skillington's group from Australia, ${ }^{5}$ however, recently reported freedom from moderate or severe AI of $85 \%$ at 20 years (with 10 patients at risk) in a cohort of 129 patients with a mean age of 34.7 years followed up for a mean of 9.6 years. Skillington uses only a modified aortic root inclusion technique, and his results are unique for this subgroup of patients, with other recent series showing a much higher rate of $\mathrm{AI}$ in patients with preoperative $\mathrm{AI}$ and $\mathrm{BAV}$, regardless of the technique used to implant the pulmonary autograft in the aortic position. ${ }^{2-4} \mathrm{I}$ believe that some genetic abnormality in the pulmonary valve of patients with the phenotype of BAV and AI causes premature failure of the pulmonary autograft and that the Ross procedure should be used with caution in this subgroup of patients with BAV until further information becomes available.

\section{References}

1. Sharifulin R, Bogachev-Prokophiev A, Zheleznev S, Demin I, Pivkin A, Afanasyev A, et al. Factors impacting long-term pulmonary autograft 
durability after the Ross procedure. J Thorac Cardiovasc Surg. 2019;157: 134-41.e3.

2. David TE, Ouzounian M, David CM, Lafreniere-Roula M, Manlhiot C. Late results of the Ross procedure. J Thorac Cardiovasc Surg. 2019;157:201-8.

3. Sievers HH, Stierle U, Petersen M, Klotz S, Richardt D, Diwoky M, et al. Valve performance classification in 630 subcoronary Ross patients over 22 years. $J$ Thorac Cardiovasc Surg. 2018;156:79-86.e2.
4. Martin E, Mohammadi S, Jacques F, Kalavrouziotis D, Voisine P, Doyle D, et al Clinical outcomes following the Ross procedure in adults: a 25-year longitudinal study. J Am Coll Cardiol. 2017;70:1890-9.

5. Poh CL, Buratto E, Larobina M, Wynnea R, O'Keefe M, Goldblatt J, et al. The Ross procedure in adults presenting with bicuspid aortic valve and pure aortic regurgitation: $85 \%$ freedom from reoperation at 20 years. Eur J Cardiothorac Surg. March 12, 2018 [Epub ahead of print]. 